\section{Female sexuality in marketing communication and effects on the millennial buying decisions in fashion industry in Nigeria}

Millennial buying decisions

\author{
Ayodele Oniku and Anthonia Farayola Joaquim
}

Department of Business Administration, Faculty of Management Sciences, University of Lagos, Lagos, Nigeria
Received 21 September 2020 Revised 8 December 2020 12 January 2021 Accepted 30 January 2021

\begin{abstract}
Purpose - The study aims to examine female sexuality in marketing communications and how it shapes the millennial buying decisions in the fashion industry. The focus of the study is to connect fashion industry and marketing communication to understand how female sexuality influence buying behaviours and decisions of the millennial.
\end{abstract}

Design/methodology/approach - The study was underpinned by the dimensions of skin colour, brand image and market share in sexual appealing marketing communication, and the millennial in the study comprises youths between the age of 21 and 40 years and demographically defined by Wells and Guber (1966) as bachelors, Full nests 1 and 2. Multistage stage sampling was used with a structured questionnaire.

Findings - Findings show that youths, 2019 buying decisions and behaviours are strategically influenced by different manifestations of female sexuality in the context of the study and equally affect market share and patronage.

Research limitations/implications - The study shows what shapes the marketing communication strategies of the rising fashion industry but is limited to the millennial buying decisions and not the larger fashion industry consumers.

Practical implications - The needs for fashion industry to understand the influence of increasing use of female sexuality in marketing communication on male and female consumers and the effects on their respective buying behaviours is strategic to the industry as shown in the study.

Social implications - Female sexuality in marketing communication is strategic to fashion industry in today's market among youths.

Originality/value - The millennial constitutes a larger percentage of the developing economy market with rising income thus the need to understand their buying behaviours in the fashion industry

Keywords Fashion, Millennial, Brand image, Patronage, Marketing communication, Female sexuality

Paper type Conceptual paper

\section{Introduction}

1.1 Fashion industry

The prominent products that define fashion are clothes, accessories and footwear. The evolution of fashion industries is seen through the changes in lifestyle and shopping

(C) Ayodele Oniku and Anthonia Farayola Joaquim. Published in Rajagiri Management Journal. Published by Emerald Publishing Limited. This article is published under the Creative Commons Attribution (CC BY 4.0) licence. Anyone may reproduce, distribute, translate and create derivative works of this article (for both commercial and non-commercial purposes), subject to full attribution to the original publication and authors. The full terms of this licence may be seen at http:// creativecommons.org/licences/by/4.0/legalcode

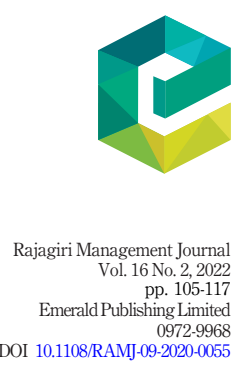


RAMJ

16,2

106

behaviours in society. Importantly, the Nigerian fashion industry is a billion-dollar industry that has grown from the traditional African fashion to western and continental fashion styles to meet the needs of the teeming population, especially the vibrant millennial who are dynamic and trendy in their demands for fashion and related items. Nigerian millennial's fashion is defined by their demographic characteristics in that they are in the brackets of professionals, outdoorsy, students, married, upward mobile, religious, socialites, traditionalists, etc.; hence, their fashion desire and needs are defined on these spectra.

Since the emergence of modern advertising in the 1920s, and later the other marketing campaigns and the shift from text-based advertisements to visual advertisements followed by the use of psychologically sophisticated messages, there has been an opportunity for a very powerful cultural resonance for advertisements among consumers. Advertisers globally, Nigeria inclusive, have had to constantly ponder on creative ways to appeal to the interest of consumers and influence their decision making when buying fashion apparels. Equally, sexiness is a trend amongst today's youths, and marketers are creatively identifying sex with fashion apparels to catch the attention of consumers in the largely saturated industry (Reichert et al., 2001). Studies by Pope et al. (2004); Severn et al. (1990) show that fashion consumers are more interested in adverts with sexually appealing models in it. Hence, it can be inferred that the fashion designers, retailers, fashionistas and youths are imbued with ubiquity of sex-appealing fashion orientation, and this has changed perception and image of today's fashion industry.

A sexual advertisement is one that triggers a sensual stimulus or arouses pleasurable response in a person's senses through its visuals or audio messages. Some of these advertisements are sexually implied or subtly implied (Reichert, 2002). Sexual marketing elicits an established effort that resorts to gaining attention and its increase in advertising has led to increased likelihood for persuasion. The fashion industry often addresses consumers and potential consumers with sexualized advertising to exude attention, interest, desire and action/purchase of the product.

This research determines if women's sexuality in marketing campaign/communication has effects on youths'/millennial buying behaviour that improve patronage in the fashion industry.

\section{Literature review}

\subsection{Women sexuality and increased patronage}

Women sexuality is more than physical sex but generally encompasses the physical dimensions of the body, as well as size, skin colour, height and the perception people have about certain body types. Like many other markets, Nigerian advertising industry is also inundated with women objectification and this frequently involved displaying parts of women bodies, like legs or chests which usually tilt people's attention towards sexual appeal. It is believed that women are used as supporting acts in advertising, also that women beautify advertisements and make adverts more appealing to the targeted audience. The use of women sexuality in marketing helps in creating interest in products which might result in its eventual purchase. An existing study affirms that the beauty and fashion industries patronize consumers by selling women to them, making them slimmer, youthful and more attractive (O'Neil, 2014). This is as a result of the perception that to be able to secure consumer's interest and eventual purchase, marketers must decorate the stimulus in creative ways including making sure it is pleasant to the eyes (Hoyer and Maclnnis, 2010). For instance, Petrecca (2007) confirms 
the effects of sex appealing on advertisement of AXE deodorant on men and the resultant increase of $14 \%$ in sales. Thus, the issue of sexuality on consumers' gender difference is strategic in purchase behaviours in fashion industry (Thomas and Gierl, 2015).

Equally, physical characteristics are considered more pronounced among men, as men are more visually oriented than women in regards to sexual appeal and arousal (Ramirez and Reichert, 2000). Jones and Reid (2011) examine participants who were shown very erotic adverts featuring female models and asking them to identify the degree to which they found the advertisement offensive; it was discovered the most offended participants were the female participants. Reichert et al. (2007) also examine if purchase intention of a promoted product was affected by the objectification of female models in an advert, and it was discovered that male consumers were unaffected while female consumers had a negative response towards the advert. This finding shows that there is a gender difference and sensitivity regarding female sexualization. Thus, it is reported that both genders are conventionally portrayed in a way that reveals inequality and this has continued through the expansion and diversification of media advertising through decades (Kuipers et al., 2017).

According to Lombardot (2007), men have positive attitudes towards sexualized women but a negative or neutral reaction to sexualized male models. Generally, women have a much more negative reaction to sexualized advertisements than men do due to the reason that women are mostly portrayed as sex objects (LaTour and Henthorne, 1993). Thus, it will be more difficult for women to have a positive reaction or buy products that are associated with sexualized marketing. Equally, adverts that feature women in casual, recreational sex received more favourable responses from men than women, but adverts that feature sex in association with relational commitment from both partners receives more favourable responses from women than men (Dahl, Sengupta, and Vohs, 2009). Imperatively, advertisers need to consider the gender of consumers before identifying the product with sexualized advertisements. In other words, when there is a strong fit, there is a positive response from women that might lead to the eventual purchase, whereas men respond favourably regardless of the level of fit (Putrevu, 2008). Women, according to Barletta (2006) are the most dominant product consumers in the 21st century. The place of women in society has changed as women nowadays are educated, powerful and have a more dominating purchasing power than men. Women spread information about products, whereas men tend to keep information to themselves. Word-of mouth marketing is now a big group in this same target verdict. Thus, we hypothesise the following:

H1. Women sexualisation in marketing campaign/communication has no effects on patronage among female youths in the fashion industry.

H2. Women sexualization in marketing campaign/communication has no effects on patronage among male youths in the fashion industry.

\subsection{Sexual appealing marketing communications and consumer psychology}

According to Witt (1999), there are four types of consumer psychological buttons: need, wants, desires and fears, and these variables motivate consumers to buy and implicitly influence fashion marketers to look beyond the physical features of apparels but to focus on the satisfaction and idealize look that clothing can provide. Sexual appeal in marketing communications is not as hidden as it once was; in fact, it is now set as a landmark of value. This further affects fashion parlance that is connoted or coloured with sexuality (Anabila et al., 2015). 
RAMJ

16,2

108
Consumers vary from different age groups; thus, it is important to attract the attention of consumers considering their age groups and their perceived interests, hence things such as music and fashion appeal to a younger generation than the old. Consumers might also consider price as a determining factor in their buying decision as some believe in a pricequality relationship, that is, the higher the price, the better the quality (Solomon et al., 2002). Although sexual appealing marketing communications may catch the attention of consumers, there are negative attitudes towards these commercials as soon as the use of nude models is not related to or necessary in the context of the product or service. A sexual advert that is unrelated to the product can interrupt the message and eventually damage the image of the company (Ouversloot and Duncan, 2008).

\subsection{Sexual appealing marketing communications and brand image}

The idea behind brand image is that the consumer is not purchasing just the product/service but also the image associated with the product/service. Brand images ought to be positive, distinctive and direct. Brand images can be strengthened using brand communications like advertising, packaging, word of mouth publicity and other promotional tools. Today, consumers possess enormous information about brands, products and companies. So, to build a strong brand image, the frequent or prospective buyers need to be knowledgeable about the right structures so that they give a positive response to the marketing strategies. Marketing communications play an essential role in influencing that knowledge. Marketing communications is seen as the voice of the company and its brand, and it is a corridor by which relationships between the products and consumers are built. It fosters brand image and equity through establishing and maintaining recall of the brand and encouraging sales and shareholder value (Luo and Donthu, 2006). Due to a saturated market and presence of hundreds of adverts on a daily basis, proponents of sex and female sexuality in marketing claim that sexually appealing marketing communications sell their products which in turn create satisfaction for the customers. In many cases, sexual appealing marketing communications are vital to brand image.

These sexual appealing marketing communications must, however, be incorporated to pass a consistent message and achieve a calculated positioning by creating awareness of the brand, incorporating the right associations to the brand image in the consumer's mind, encouraging positive brand judgements and facilitating a stronger brand connection. From a customer-based perspective, the use of sexual appealing marketing communications increases brand equity and sales in various ways (Keller, 2007). Hence, it is hypothesised:

H3. There is no relationship between sexual appeal marketing in the fashion industry and a positive brand image among youths.

Importantly, like other goods and services fashion retailing equally relies on communication tools like advertising, public relations, publicity, sales promotions, event marketing, sponsorship, etc. The fact is that when customers are satisfied, they might further refer the product by sharing their experience with friends and family. This is an indirect method of marketing. The main goal of a company is to provide the satisfaction to the needs, wants and demands of their consumers. Importantly, due to the peculiarity of fashion that changes with seasons and regions it behooves on organisations to adopt global communication strategies to meet customers' expectations across markets (Wan et al., 2014).

\subsection{Female sexuality}

Sexuality encompasses a broad spectrum and is also personal. It is understood and recognised as the sexual emotions and attraction one feels towards others. Sexuality is 
diverse with everyone as some people are attracted to one thing whilst others are attracted to a number of things which may include physique, colour, gender and so on. Sexuality can be affected by a number of factors such as cultural, social, political, legal, philosophical, moral, ethical and religious aspects of one's life.

Heller (2000) opines that sex is currently more widespread in mass media today than it was in the early twentieth century. However, over the past century, the human body has been oppressed in advertising and it has been aggressively used to sell products. Heller (2000) furthers and breaks down female sexuality into:

- Sexuality being unsuitably forced on girls such as push-up bras.

- The narrow and impossible standards for female attractiveness or beauty such as magazines with skinny models, straight hair, miniskirts and so on.

- When the sexual appeal is valued above all other features such as intelligence and skills.

- Sexual objectification involving women being portrayed as an object of desire or domesticity rather than as a whole being.

When people are asked to identify the characteristics in advertising that contains nudity they refer to short skirts, tight tops, muscular arms, bikinis and lingerie. The term nudity does not imply that models are completely unclothed; a suggestive dress is often represented by open blouses with partially exposed cleavage, tight-fitting clothing that highlights the body (Sherman and Quester, 2005). In other words, nudity denotes the amount of clothing or style models wear in adverts. Nudity is exceptionally uncommon in mainstream advertising and therefore it is often symbolized by side and back shots of the model, tub and shower scenes, in some cases frontal nudity, and it is frequently seen in advertisements for fashion retailers (Nelson and Paek, 2005).

Nudity is often times operationalized as various stages of undress - demure, suggestive, partially-clad and nude are the four levels of nudity identified by Soley and Reid (1988).

Demure is an "everyday dress" which includes shorts but exclude mini-skirts, bum shorts and underwear. Suggestive represents clothing that partially expose the upper body such an unbuttoned blouse showing cleavage, tight fitting clothes to accentuate figure and mini-skirts (Lambiase and Reichert, 2003; Soley and Reid, 1988). Models are furthermore, considered partially-clad when they are in underwear or bathing suits (Soley and Reid, 1988). However, complete nudity is however extremely rare in mainstream advertising.

Reichert and Ramirez (2000) corroborate that nudity is also an aspect of sex appeal in advertising and it constitutes a component of provocative appeal in advertising (Lee et al., 2017). The work of Lee et al. (2017) explains that products acceptability and patronage is linked to nudity, and may not only have an effect on how much the advertisement is liked or disliked but also how provocative the advertisement is (the less similarity, the more provocative). The study further reveals that age and gender are variables that affect the way advertisements are perceived. Dissatisfaction with sexual advertisements is discouraged by old customers and encouraged by men who support half clad women being featured in advertisements. The earlier study of Peterson and Kerin (1977) on females in advertising expresses critic's view that such adverts "portray women as dependent and not career motivated" which is why it pushes "old-fashioned and mundane gender role stereotypes" (p. 59). Equally, the work Sinami and Matoshi (2019) on alcohol advertisement concludes that women are an object of seduction. Hence, men are often more fascinated by nude female models in advertisements and coincidentally these nude models are generally not well 
RAMJ

16,2

received, especially when there is no relationship with the advertised product and sexual image i.e. product and model congruency. Hence, it is hypothesised that:

H4. There is no relationship between skin color in sexual appealing marketing communications and consumer psychology among youths in the fashion industry.

The components of female sexuality and sexuality at large in marketing communication comprise of the following and their operational frameworks are strategic to project sexiness that works on consumers' sub-consciousness.

Sexual referents are oral components or combinations of vocal and graphical message components that slightly refer to sex or those elements that prompts sex in an individual's mind, and it is implicit because allusions to sex are indirect (Reichert, 2002; Lambiase and Reichert, 2003; Reid et al., 1984; Pelt, 2010). Nilaweera and Dinuka (2005) defines sexual embeds as "a form of sexual depiction that is perceived unconsciously" (p.25). Sexual embeds refer to activity that contains sexual materials either subtle or not. Sexual embeds can be categorized into sexual imagery and concealed erotic images and words. Even though sexual embeds contain subtle sexual content, these embeds have the ability to activate subconscious recognition, kindle arousal and encourage purchase (Nelson and Paek, 2005; Anabila et al., 2015; Furnham and Mainaud, 2011; Leka et al., 2013). Sexual advertising or selling via sex is the adoption of sexual content or suggestions in advertising to help sell a product or service. Sex in advertising can be highly overt and recognizable or extremely subtle. It ranges from relative exhibitions of sexual acts, use of both facial and bodily decorations to enhance certain bodily features. Sexual appeal in advertising also involves use of other areas of cognitive response. According to Alam et al. (2019), sex propels people and arouses their sensitive side. This makes product messages memorable and easy to relate to. These advertisements also provoke the desire to purchase the product or service being advertised. Many brands acknowledge that they are able to create more employment and benefit the society because they sell more through sexual advertisements (Alam et al., 2019).

Smith (2002) concludes that sexual advertisements enhance purchase intentions but admit that these advertisements are targeted to the respondent group and this may result in the approval of these sexual advertisements. Thus, it is hypothesised that:

H5. There is no relationship between reliance on sexualized marketing communications and an improved market share

\section{Methods}

The study adapts triangulation whereby both quantitative and qualitative approaches are applied to analyse the data. Millennial which formed the respondents for the study are working class youths between the age of 21 and 40 years who spread across students in tertiary institutions and working class groups - bachelors, newlyweds and full nest 1 and full nest 2 (Wells and Guber, 1966). Lagos State was chosen for the study being the business hub of Nigeria and one of the attractive centres for African fashion projects. Since, 2010 the industry has been contributing an average of $17 \%$ to the GDP (NBS, 2016), and the popular Lagos Fashion Week remains one of the global events that attracts global audience to budding Nigerian fashion industry. Thus, the study adopted cross-sectional research design while the area of study was Lagos Metropolis with the sample size of 324 drawn across the youths in the city made up of Lagos Island and Mainland axis.

A structured questionnaire was used to collect data while multi-stage sampling technique was employed in the process of questionnaire administration. Pearson product 
moment correlation (PPMC) was used to test the research hypotheses based on the need and usage to understand the strength and direction of relationship between two variables (Pallant, 2007). The instrument for the study was developed based on the extant studies in female sexuality in fashion industry and marketing communication (Lambaise and Reichert, 2003; Reichert and Ramirez, 2000; Peterson and Kerin, 1977). Importantly, the administration of the questionnaire covered both the consumers and the fashion retailing outlets in the city. The consistency of Cronbach alpha test ranged from 0.648 to 0.791 which was found acceptable for the study, and the standard deviation results show wider spread out of the measurement.

The data on the fashion houses/retailers revealed that all organisations involved in the study were indigenously owned; years of business existence range from 2 - 10 years; and retailing operations modes are online, offline and combination or duo of online/offline. Among the notable fashion outlets and retailers for the study were Fit ' $n$ ' Stiches; Haute Signature; King Toni House of Fashion; Oak's Signature, etc.

\subsection{Testing of hypotheses}

H1: There is no relationship between women sexualization in marketing communications/ campaigns and female youths' patronage in the fashion industry (Table 1).

Decision: Since the $p$-value is lesser than $5 \%$ level of significance $(0.017>0.05)$, the correlation relationship between women sexualization in marketing communications/ campaigns and increased patronage among female youths in the fashion industry is linear, strong, positive and significant $(r=0.105)$.

H2. There is no relationship between women sexualization in marketing campaign/ communication and male youths' patronage in fashion industry (Table 2).

Decision: As the $p$-value is lesser than $5 \%$ level of significance $(0.001,0.000$ and $0.000>0.05)$, therefore, the three null hypotheses were rejected and the alternate hypothesis is accepted. In addition, the correlation relationship between women sexualization in marketing campaign/communication and increased patronage among male youths in fashion industry is linear, strong, positive and significant $(r=0.191,0.329$ and 0.328$)$. Impliedly, there is a relationship between women sexualization in marketing campaign/ communication and effects on men's patronage in fashion industry.

From these two statistical results, it can be inferred that women sexuality has a greater impact on increased patronage among male youths in the fashion industry than female youths.

H3: There is no relationship between sexual appeal marketing in the fashion industry and a positive brand image among youths (Table 3).

\begin{tabular}{lccr}
\hline & $\begin{array}{c}\text { Women } \\
\text { sexualization }\end{array}$ & $\begin{array}{c}\text { Female consumer } \\
\text { patronage }\end{array}$ & $\begin{array}{r}\text { Table 1. } \\
\text { Pearson product }\end{array}$ \\
$\begin{array}{lccr}\text { Women used in these adverts are always beautiful, slim and sexy } & & 0.105 & \begin{array}{r}\text { moment correlation } \\
\text { Pearson Correlation }\end{array} \\
\begin{array}{l}\text { Sig. (2-tailed) } \\
N\end{array} & 1 & 0.017 & \text { the relationship } \\
\text { between women } \\
\text { sexualization and } \\
\text { Continuous patronage of the fashion apparel after contact with sexual advert } \\
\begin{array}{l}\text { Pearson Correlation } \\
\text { Sig. (2-tailed) }\end{array} & 0.105 & 324 & \text { female consumer } \\
N & 0.017 & 1 & \text { patronage (fashion } \\
\text { consumers) }\end{array}$ \\
\hline
\end{tabular}

Millennial buying decisions

\section{$+2$}


RAMJ

16,2

112

Table 2.

Pearson product moment correlation the relationship between women sexualization and men's patronage (fashion consumers)

Decision: As the $p$-value is lesser than $5 \%$ level of significance $(0.000>0.05)$. In addition, the correlation relationship between sexual appeal marketing in the fashion industry and positive brand image among youths is linear, strong, positive and significant $(r=0.478)$. Impliedly, there is a relationship between sexual appeal marketing in the fashion industry and positive brand image among youths.

H4. There is no relationship between skin colour in sexual appealing marketing communications and consumer psychology among youths in fashion industry (Table 4).

Decision: As the $p$-value is lesser than $5 \%$ level of significance $(0.009>0.05)$, the correlation relationship between skin colour in sexual appealing marketing communications and consumer psychology is linear, strong, positive and significant $(r=0.325)$. Impliedly, there is a relationship between skin colour in sexual appealing marketing communications and consumer psychology among youths in fashion industry.

H5: There is no relationship between reliance on sexualized marketing communications and higher market share. (Table 5)

Decision: As the $p$-value is lesser than $5 \%$ level of significance $(0.000>0.05)$. In addition, the correlation relationship between reliance on sexualized marketing communications and a higher market share is linear, strong, positive and significant $(r=0.323)$. Impliedly, there is a relationship between reliance on sexualized marketing communications and higher market share.

\begin{tabular}{|c|c|c|c|}
\hline & Women sexualization & $\begin{array}{c}\text { Idealized models in } \\
\text { fashion advertisements }\end{array}$ & $\begin{array}{c}\text { Men's } \\
\text { patronage }\end{array}$ \\
\hline \multicolumn{4}{|c|}{ Men are the target market of sexual appealing advertisements } \\
\hline Pearson Correlation & 1 & $0.328 * *$ & $0.191 * *$ \\
\hline Sig. (2-tailed) & & 0.000 & 0.001 \\
\hline$N$ & 324 & 324 & 324 \\
\hline \multicolumn{4}{|c|}{ Idealized models in fashion advertisements encourage men's patronage of those fashion brands } \\
\hline Pearson Correlation & $0.328^{* *}$ & 1 & $0.329 * *$ \\
\hline Sig. (2-tailed) & 0.000 & & 0.000 \\
\hline$N$ & 324 & 324 & 324 \\
\hline \multicolumn{4}{|c|}{ Men are encouraged to patronise fashion apparels that depict sexuality } \\
\hline Pearson Correlation & $0.191^{* *}$ & $0.329 * *$ & 1 \\
\hline Sig. (2-tailed) & 0.001 & 0.000 & \\
\hline$N$ & 324 & 324 & 324 \\
\hline
\end{tabular}

Sexualized marketing communications bring out the beauty in fashion apparels
Sexualized marketing leaves a good image of the fashion brand

\section{Table 3.}

Pearson product moment correlation the relationship between sexualized marketing communications and positive Brand image (fashion consumers)
Sexualized marketing communications bring out the beauty in fashion apparels

$\begin{array}{lcc}\text { Pearson Correlation } & 1 & 0.478^{* *} \\ \text { Sig. (2-tailed) } & 324 & 0.000 \\ N & 0.478^{* *} & 324 \\ \text { Sexualized marketing leaves a good image of the fashion brand } & 1 \\ \begin{array}{l}\text { Pearson Correlation } \\ \text { Sig. (2-tailed) } \\ N\end{array} \quad 324 & 324 \\ & \\ \text { Note: **Correlation is significant at the } 0.05 \text { level (two-tailed) } & \end{array}$




\section{Findings}

4.1 Framework (see attached framework) source: Authors (2020)

From the analysis, the null hypotheses were rejected because of the directions of the relationship between the variables which are all positive, and the strength of the relationship (from the r value: $0.105 ; 0.328 ; 0.226 ; 0.325 ; 0.478 ; 0.323$ ) shows a range from small to medium

Millennial buying decisions
Skin colour in sexual appealing marketing communications
Consumer psychology

The skin colour of models in sexual appealing marketing communications are significant Pearson Correlation Sig. (2-tailed) $N$ 324

Skin colour of models make fashion apparels more attractive to consumers Pearson Correlation Sig. (2-tailed) N

$0.226^{* * *}$

0.000 324

324

Note: **Correlation is significant at the 0.05 level (two-tailed)

\section{3}

Table 4.

Pearson product moment correlation

the relationship between skin colour and consumer psychology (fashion consumers)

\section{Sexualized marketing communications}

Higher market share

People will buy clothes more when the models are attractive

Pearson Correlation

Sig. (2-tailed)

N

324

0.000

Fashion brands that pay much detail to models do better in sales

Pearson Correlation

Sig. (2-tailed)

$N$

$0.370^{* * *}$

0.000

324

1

324

Note: **Correlation is significant at the 0.05 level (two-tailed)
Table 5.

Pearson product moment correlation the relationship between sexualized marketing communications and higher market share (fashion consumers)

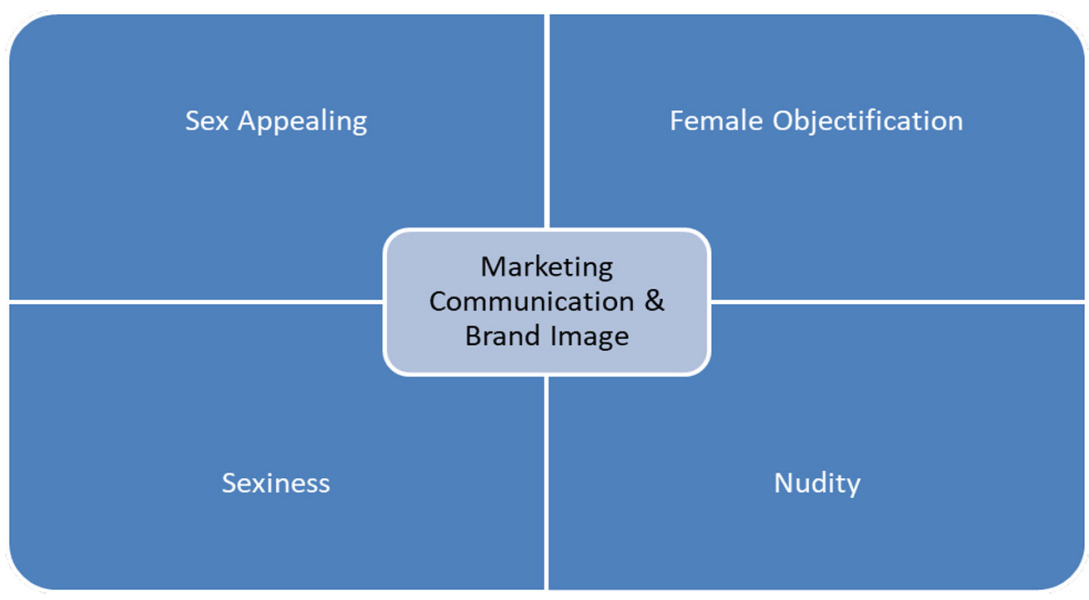

Figure 1. Framework 
RAMJ

16,2

strength of relationship (Pallant, 2007). Succinctly, it can be summed up that the effectiveness of female sexuality in communication for effective brand image building depends on the quartet of Sex Appealing; Female Objectification; Sexiness; and Nudity. The case of female objectification is anchored on the effect of female skin/complexion on influence of marketing communication on buyers' buying decisions and behaviours. Equally, nudity in this context is not nakedness or sexual nudity, but any form of female sexuality and image that embraces revealing clothing and exposure of cleavage and other sensual parts of the body. From the analysis, the interconnectedness of the factors influences consumers' understanding of brand image in fashion industry in order to gain positive brand patronage. In other words, the integration of female sexuality built on the quartet into marketing communication will positively affect brand image in fashion industry.

\subsection{Implications and conclusion}

The focus of the study on the youths recognises the pivotal roles of youths in the economy coupled with the emerging and budding demand for fashion to portray western and African culture respectively which the fashion industry has ubiquitously achieved in the system. From the analysis, it is revealed that women used in the adverts are always beautiful, slim, sexy and largely models, and that fashion retailers capitalise on both the implicit and explicit sexual effects of the image and models to attract customers' patronage. This corroborates Smith (2002) in the study of Victoria Secret's operations that emphasises that women fashion advertisements focus on women's physical appearance as instruments used for selling themselves as well as their fashion attires. In other words, women objectification is a strategic instrument in buying decision that positively affects patronage

Importantly, skin colour of models plays dual role of women objectification and sexual appealing in marketing communications. Thus, skin colour of models affects consumer's decision to purchase fashion apparel and fashion consumers are more attracted to adverts with dark skinned models. Impliedly, skin colour is strategic in selection of models and marketing communication images for fashions meant for Nigerian youths, and this might influence consumers' decision on selection of choice of apparels quality, design, colours and other exterior features. However, the works of Phoenix (2014) and Hunter (2007) negate the view and argue that black women's current disposition to cosmetic surgery as a logical response to opportunities in the global market space where been light-skinned has more economic and social benefits.

Female sexualization in fashion marketing is becoming popular with many known fashion brands who predominantly try to draw customer's attention and desire because there is continuous patronage of the fashion apparel after interaction with sexual models and adverts. Thus, it can be established female objectification works along with women sexualization which affect consumers' behaviour and improve patronage among female youths in the fashion industry. Findings equally prove that men are encouraged to patronise fashion brands that elicit sexuality of women and objectifies models in the fashion industry. According to Reichert and McRee-Walker (2005), people are more enticed by the opposite gender and tend to see them as desirable "objects". This position favours the theory that people refer to the opposite sex as potential sexual partners (Maner et al., 2007; Wan, Luk and Chow, 2014). By and large, women sexuality in marketing communication affects genders and this is premised on usage of sexy models, exposure of cleavages and other sex appealing strategies that have the same effects on both male and female youths to sustain their patronage in fashion industry.

In addition, the study shows that fashion brands with sexual appealing models attract more attention and this creates sexiness factor that informs users' perception of individual 
appearance. In other words, consumers' appearance is important in buying decisions, hence the sexiness factor resonates with personal appearance of users or consumers. Hence, sexualized marketing communication leaves a good image of the fashion brand. This is an indication that sexualized marketing communications in the fashion industry elicit a positive brand image for youths in the fashion industry. Thus, sexiness instils the consciousness that image of sexy women is healthy for brand acceptability among men and vice versa.

In conclusion, the study has established that female sexuality in marketing communications has a strong impact on consumer psychology and behaviour in the fashion industry. Hence, for fashion industry to achieve its marketing communication objectives they need to integrate female sexualization in the design of advertising campaigns so as to be able to attract customers but must note that product congruence is important. Marczyk (2017) reveals that female sexuality is less likely to sell a product if the product being sold is incongruent with the sexual appeal. Pertinently, it becomes imperative for fashion retailers and the industry at large to recognise the strategic implications and effects of women sexualisation and sexuality in boosting brand image and improving patronage in the industry.

\section{References}

Alam, M.M., Aliyu, A. and Shahriar, S.M. (2019), "Presenting women as sexual objects in marketing communications. Perspective of morality, ethics and religion", Journal of Islamic Marketing, Vol. 10 No. 3, pp. 911-927.

Anabila, P., Tagoe, C. and Asare, S. (2015), "Consumer perception of sex appeal advertising: a high context cultural perspective", The IUP Journal of Marketing Management, XIV, No. 4, pp. 35-55.

Furnham, A. and Mainaud, L. (2011), "The effect of french television sexual program content on the recall of sexual and nonsexual advertisements", The Journal of Sex Research, Vol. 48 No. 6, pp. 590-598.

Hoyer, W.D. and Maclnnis, D.J. (2010), Consumer Behaviour, (5th ed.), Houghton Miffling Company, Boston.

Jones, S.C. and Reid, A. (2011), "Sex and sexism in Australian alcohol advertising: (why) are women more offended than men?", Contemporary Management Research, Sansia, Vol. 7 No. 3, pp. 211-230.

Kuipers, G., Van der Laan, E. and Arfini, E.A.G. (2017), "Gender models: changing representations and intersecting roles in dutch and Italian fashion magazines.1982-2011", Journal of Gender Studies, Vol. 26 No. 6, pp. 632-648.

Lambiase, J.J. and Reichert, T. (2003), "Sex-online and in internet advertising", in Reichert, T. and Lambiase, J.J. (Eds), LEA's Communication Series: Sex in Advertising: Perspectives on the Erotic Appeal, pp. 247-269.

Lambaise, J. and Reichert, T. (2003), "How to get kissably close: examining how advertisers appeal to consumers' sexual needs and desires", Sexuality \& Culture, New York, Vol. 7 No. 3, pp. 120-136.

LaTour, M.S. and Henthorne, T.L. (1993), "Female nudity: attitudes towards the ad and the brand and implications for advertising strategy", Journal of Consumer Marketing, Vol. 10 No. 3, pp. 25-32.

Lee, S.M., Heflick, N.A., Park, J.W., Heeyoung, K. and Koo, J. (2017), "When sex doesn't sell to men: morality salience, disgust and the appeal of products and advertisements featuring sexualised women", Motivation \& Emotion, New York, Vol. 41 No. 4, pp. 478-491.

Lombardot, É. (2007), "Nudity in advertising: what influence on attention-getting and brand recall?", Recherche Et Applications En Marketing (English Edition), Vol. 22 No. 4, pp. 23-41.
Millennial buying decisions 
RAMJ

16,2

Luo, X. and Donthu, T. (2006), "Marketing's credibility: a longitudinal investigation of marketing communication productivity and shareholder value", Journal of Marketing, Vol. 70 No. 4, pp. 70-91.

Maner, J.K., Gailliot, M.T., Rouby, D.A. and Miller, S.L. (2007), “Can’t take my eyes off you: attentional adhesion to mates and rivals", Journal of Personality and Social Psychology, Vol. 93 No. 3, pp. 389-401.

Marczyk, J. (2017), “Understanding sex in advertising”, Psychology Today, (June 26), available at: www. google.com/amp/s/www.psychologytoday.com/intl/blog/poppsych/201706/understanding-sex-inadvertising\%3famP (accessed 10 August 2020).

Nelson, M.R. and Paek, H. (2005), "Cross cultural differences in sexual advertising content in a transnational women's magazine”, Sex Roles, Vol. 53 Nos 5/6, pp. 371-383.

Nilaweera, U. and Dinuka, W. (2005), "The impact of cultural values on the effectiveness of television commercials with female sexual appeal: a Sri Lankan study", South Asian Journal of Management, Vol. 12 No. 3, pp. 7-20.

O'Neil, A. (2014), "A call for truth in the fashion pages: what the global trend in advertising regulation means for US beauty and fashion advertisers", Journal of Global Legal Studies, Vol. 21 No. 2, pp. 619-641.

Ouversloot, H. and Duncan, T. (2008), Integrated Marketing Communication, McGraw Hill, New York.

Pallant, J. (2007), SPSS Survival Manual, (3rd ed.), McGraw Hill, Berkshire.

Pelt, A. (2010), "Advertising agency: print culture and female sexuality in 'Nausicaa”, James Joyce Quarterly, Vol. 48 No. 1, pp. 41-53.

Petrecca, L. (2007), "Axe ads up the promise of sex appeal”, USA Today (April 18), available at: www. usatoday.com/money/advertising/2007-04-17-axe-sell-usat_N.htm (accessed May 26, 2019).

Peterson, A.R. and Kerin, R.A. (1977), "The female role in advertisements: some experimental evidence", Journal of Marketing, Vol. 41 No. 4, pp. 59-63.

Pope, N.K.L., Voges, K.E. and Brown, M.R. (2004), "The effect of provocation in the form of mild erotica on attitude to the ad and corporate image: differences between cause-related and product-based advertising", Journal of Advertising, Vol. 33 No. 1, pp. 69-82.

Putrevu, S. (2008), "Consumer responses toward sexual and nonsexual appeals: the influence of involvement, need for cognition (NFC), and gender", Journal of Advertising, Vol. 37 No. 2, pp. 57-70.

Ramirez, A. and Reichert, T. (2000), "Defining sexually oriented appeals in advertising: a grounded theory investigation", Advances in Consumer Research, Vol. 27, pp. 267-273.

Reichert, T. (2002), "Sex in advertising: a review of content, effects and functions of sexual information in consumer advertising in", Annual Review of Sex Research, Vol. 13, pp. 241-273.

Reichert, T. and McRee-Walker, K. (2005), "Sex and magazine promotion: the effects of sexualized subscription cards on magazine attitudes, interest, and purchase intention", Journal of Promotion Management, Vol. 11 Nos 2/3, pp. 131-141.

Reichert, T., Heckler, S.E. and Jackson, S. (2001), “The effect of sexual social marketing appeals on cognitive processing and persuasion", Journal of Advertising, Vol. 30 No. 1, pp. 13-27.

Reichert, T., Latour, M.S., Lambiase, J.J. and Adkins, M. (2007), "A test of media literacy effects and sexual objectification in advertising", Journal of Current Issues \& Research in Advertising, Vol. 29 No. 1, pp. 81-92.

Sherman, C. and Quester, P. (2005), "The influence of product/nudity congruence on advertising effectiveness", Journal of Promotion Management, Vol. 11 Nos 2/3, pp. 61-89.

Sinami, R. and Matoshi, E. (2019), "Portrayal of woman in beer advertising in Kosovo (case of PEJA beer)", Acta Universitatis Danubius Communicatio, - AUDC, Vol. 13, Vol. 2, pp. 69-83. 
Soley, L.C. and Reid, L.N. (1988), “Taking it off: are models in magazine ads wearing less?”, Journalism \& Mass Communication Quarterly, Vol. 65 No. 4, pp. 960-966.

Solomon, M.R., Bamossy, G., Askegaard, S. and Hogg, K.M. (2002), Consumer Behaviour: A European Perspective, (3rd ed), FT Prentice Hall, England.

Millennial buying decisions

Thomas, S. and Gierl, H. (2015), "Too hot or not? Consumer responses to different levels of eroticism in advertisements depending on consumer and model gender", Journal of Research and Management, Vol. 37 No. 1, pp. 24-41.

Wan, W., Luk, C.L. and Chow, C.,W.C. (2014), "Consumer responses to sexual advertising: the intersection of modernization, evolution and international marketing", Journal of International Business Studies, Vol. 45 No. 6, pp. 751-782.

\section{Further reading}

Friedman, V. (2015), "The Abercrombie and Fitch makeover: a review”, The New York Times, pp. 1-3, available at: www.nytimes.com/2015/04/28/fashion/abercrombie-and-fitch-has-a-makeover. $\mathrm{html}$ ?rref=collection/timestopic/Abercrombie\&FitchCo.\&action=click\&contentCollection=business\& region=stream\&module=stream_unit\&version=latest\&contentPlacement=7\&pgtype=collec (accessed 26 May 2019).

Howard, T. (2005), "Ad campaigns tell women to celebrate who they are", USA Today (July, 7), available at: www.usatoday30.usatoday.com/money/advertising/2005-07-07-dove-usat_x.htm? POE=click-refer (accessed 26 May 2019).

Jones, M.Y., Stanaland, A.J.S. and Gelb, B.D. (1998), "Beefcake and cheesecake: insight for advertisers", Journal of Advertising, Vol. 27 No. 2, pp. 33-51.

LaTour, M.S. (1990), "Female nudity in print advertising: an analysis of gender differences in arousal and ad response", Psychology and Marketing, Vol. 7 No. 1, pp. 65-81.

LaTour, M.S. and Henthorne, T.L. (1994), "Female nudity in advertisements, arousal and response: a parsimonious extension”, Psychological Reports, Vol. 75 No. 3, pp. 1683-1690.

LaTour, M.S. and Herbert, J.R. (1997), "There are threats and (maybe) fear-caused arousal: theory and confusions of appeals to fear and fear arousal itself", Journal of Advertising, Vol. 26 No. 3 , pp. 45-59.

Moore, D.J. and Harris, W. (1996), "Affect intensity and the consumer's attitude toward high impact emotional advertising appeals", Journal of Advertising, Vol. 25 No. 2, pp. 37-50.

Solomon, M.R., Ashmore, R.D. and Longo, L.C. (1992), "The beauty match-up hypothesis: congruence between types of beauty and product images in advertising", Journal of Advertising, Vol. 21 No. 4, pp. 23-34.

Steadman, M. (1969), "How sexy illustrations affect brand recall", Journal of Advertising Research, Vol. 9 No. 1, pp. 15-19.

\section{Corresponding author}

Ayodele Oniku can be contacted at: ooniku@unilag.edu.ng

For instructions on how to order reprints of this article, please visit our website:

www.emeraldgrouppublishing.com/licensing/reprints.htm

Or contact us for further details: permissions@emeraldinsight.com 